\title{
MALACOFAUNA DA REGIÃO ENTREMARÉS DE PRAIAS DA ILHA DE SÃO SEBASTIÃO (SÃO PAULO, BRASIL) ${ }^{1}$
}

\author{
Lara Bellintani Salvador 2,4 \\ Osmar Domaneschi ${ }^{3}$ \\ Antonia Cecília Zacagnini Amaral ${ }^{2}$ \\ Eloisa Helena Morgado ${ }^{2}$ \\ Silvana Aparecida Henriques ${ }^{2}$
}

\begin{abstract}
INTERTIDAL MALACOfaUna OF SANDY BEACHES OF SÃo SEBASTIÃo IsLAND (SÃo PAUlo, BRAZIL). This paper reports a concise characterization, based on shell morphology, of 52 species collected during one year at intertidal regions of Barra Velha, Perequê and Engenho D'água beaches. Substrate information, species occurrence and geographic distribution are also provided.

KEY WORDS. Mollusca, sandy beaches, intertidal, São Paulo, Brazil
\end{abstract}

Há um século tiveram início os primeiros registros da malacofauna marinha do litoral norte do estado de São Paulo, com a publicação de IHERING (1897) sobre sua viagem à Ilha de São Sebastião. No decorrer desses anos, poucos foram os estudos realizados sobre levantamentos específicos da malacofauna do litoral norte do Estado de São Paulo, como pode ser verificado através da revisão feita por MigotTo et al. (1993). Esses autores incluíram em sua lista faunística 142 espécies de moluscos referidas para a região de São Sebastião e o Arquipélago dos Alcatrazes.

Além da bibliografia mencionada por MigotTo et al. (1993), merecem destaque o levantamento realizado por LOPES (1992), sobre os bivalves e gastrópodes da Praia do Saco da Ribeira, Ubatuba (São Paulo). Pode-se também mencionar os trabalhos sobre a macrofauna dessa região, efetuados por AMARAL et al. (1990) e MORGADO et al. (1990).

O presente trabalho constitui parte dos resultados obtidos com o Programa Fauna de Praia, que tem por objetivo conhecer a macrofauna bêntica da região entremarés de praias do litoral do estado de São Paulo, e desta forma, fornecer subsídios para programas de monitoramento.

1) Trabalho desenvolvido com apoio: CEBIMar/USP; FAEP/UNICAMP; CAPES.

2) Departamento de Zoologia, Instituto de Biologia, Universidade de Campinas. Caixa Postal 6109, 13083-970 Campinas, São Paulo, Brasil.

3) Departamento de Zoologia, Instituto de Biociências, Universidade de São Paulo. Caixa Postal 11461, 05422-970, São Paulo, São Paulo, Brasil.

4) Bolsista CAPES.

Revta bras. Zool. 15 (4): 1013 - 1035, 1998 
Com a finalidade de facilitar a identificação de moluscos, são fornecidos quadros com ilustrações, reunindo os principais aspectos morfológicos das famílias, bem como caracterizações das espécies da região entremarés das praias Barra Velha, Perequê e Engenho D'água (Ilha de São Sebastião, São Paulo). As caracterizações foram baseadas no exame do material coletado e auxílio da bibliografia, e são acompanhadas de ocorrência, distribuição e tipo de substrato.

\section{MATERIAL E MÉTODOS}

As praias Barra Velha, Perequê e Engenho D'água estão situadas na região centro-norte da Ilha de São Sebastião, São Paulo (23ำ $47^{\prime}$ e $23^{\circ} 50^{\prime}$ 'S; $45^{\circ} 21^{\prime}$ e $45^{\circ} 23^{\prime} \mathrm{W}$ ), voltada para o canal de mesmo nome.

A Praia Barra Velha, que ocupa a região central do canal, constitui um ambiente característico de baixa energia, com ampla faixa entremarés e suave gradiente de declividade. Nesta praia foram estudados diferentes tipos de ambiente: um com sedimentos compostos predominantemente por areia grossa, recoberta por areia fina, onde na parte superior, próxima ao supra-litoral, estabeleceu-se uma vegetação característica de manguezal devido à presença de um pequeno riacho, $\mathrm{e}$ outro, composto por sedimentos finos com aspecto areno-lodoso, bastante uniformes. As praias do Perequê e Engenho D'água, contíguas à Barra Velha, em direção ao norte, têm como características semelhantes a formação de bancos, predominantemente de areia média e grossa, recobertos por gramíneas marinhas no Perequê e misturado com pedras no Engenho D'água.

As amostragens, efetuadas entre agosto de 1992 e maio de 1993, foram realizadas com o auxílio de dois delimitadores: um cilíndrico e um quadrado $(0,01$ $\mathrm{m}^{2}$ e $0,25 \mathrm{~m}^{2}$ de área, respectivamente), enterrados até uma profundidade de $20 \mathrm{~cm}$. Posteriormente, as amostras foram triadas em peneiras de malhas de 0,5 e $1,0 \mathrm{~mm}$, no Laboratório do Centro de Biologia Marinha da Universidade de São Paulo (CEBIMar) e os organismos aí retidos, fixados em álcool a 70\%. Para a análise granulométrica do sedimento, adotou-se a metodologia descrita por SUGUIO (1973).

Os moluscos foram identificados até o nível específico, adotando-se preferencialmente a classificação proposta por ABBOTT (1974), com algumas exceções, conforme MORTON \& SCOTT (1990), LEAL (1991) e RiOS (1994). A distribuição geográfica de cada espécie foi baseada fundamentalmente em Rios $(1985,1994)$. Cada espécie é caracterizada resumidamente, com base na morfologia da concha, seguindo-se, para cada caso, um ou mais dos seguintes autores: Boss (1966), RIGHI (1971), KEEN (1971), NARCHI (1972), DAVIS (1973), ABBOTT (1974), OLIVEIRA \& Oliveira (1974), COELHO \& CAMPOS (1975), WARMKE \& ABBOTT (1975), NARCHI \& GABRIELI (1980), EISENBERG (1983), KAAS \& VAN BELLE $(1985,1987)$, Rios (1985, 1994), DANCE (1990), MORTON (1990), MORTON \& SCOTT (1990), ABBOTT \& DANCE (1991), DOMANESCHI (1995). Os exemplares identificados encontram-se depositados no Departamento de Zoologia, Instituto de Biologia, da Universidade Estadual de Campinas, sob numeração FP1 - 52 (Programa Fauna de Praia). 


\section{RESULTADOS}

A tabela I lista as 52 espécies de moluscos registradas nas três praias estudadas, sendo o maior número correspondente aos Bivalvia, com 38 espécies, seguido dos Gastropoda, com 13 (ambos com 10 famílias) e Polyplacophora, com uma única espécie.

Tabela I. Lista das espécies, acompanhada da ocorrência (+) nas três praias estudadas, Barra Velha, Perequê e Engenho D'água.

\begin{tabular}{|c|c|c|c|}
\hline Espécies & Barra Velha & Perequê & Engenho D'água \\
\hline \multicolumn{4}{|l|}{ Gastropoda } \\
\hline \multicolumn{4}{|l|}{ Trochidae } \\
\hline Calliostoma adspersum (Philippi, 1851) & & + & \\
\hline Tegula viridula (Gmelin,1791) & & & + \\
\hline \multicolumn{4}{|l|}{ Phenacolepadidae } \\
\hline Phenacolepas hamillei (Fischer, 1857) & & & + \\
\hline \multicolumn{4}{|l|}{ Modulidae } \\
\hline Modulus modulus (Linnaeus, 1758) & & & + \\
\hline \multicolumn{4}{|l|}{ Cerithiidae } \\
\hline Cerithium atratum (Born, 1778) & + & + & + \\
\hline Bittium varium (Pfeiffer, 1840) & & + & \\
\hline \multicolumn{4}{|l|}{ Naticidae } \\
\hline Polinices lacteus (Guilding, 1834) & & & + \\
\hline \multicolumn{4}{|l|}{ Muricidae } \\
\hline Trachypolia nodulosa (C.B. Adams, 1845) & & & + \\
\hline Stramonita haemastoma (Linnaeus, 1767) & & & + \\
\hline \multicolumn{4}{|l|}{ Nassariidae } \\
\hline Nassarius vibex (Say, 1822) & & & + \\
\hline \multicolumn{4}{|l|}{ Fasciolariidae } \\
\hline Leucozonia nassa (Gmelin, 1791) & & & + \\
\hline \multicolumn{4}{|l|}{ Olividae } \\
\hline Olivella minuta (Link, 1807) & + & + & + \\
\hline \multicolumn{4}{|l|}{ Bullidae } \\
\hline Bulla striata Bruguière, 1792 & + & + & + \\
\hline \multicolumn{4}{|l|}{ Polyplacophora } \\
\hline \multicolumn{4}{|l|}{ Ischnochitonidae } \\
\hline Ischnochiton striolatus (Gray, 1828) & & + & + \\
\hline \multicolumn{4}{|l|}{ Bivalvia } \\
\hline \multicolumn{4}{|l|}{ Arcidae } \\
\hline Lunarca ovalis (Bruguière, 1789) & & & + \\
\hline Arcopsis adamsi (Dall, 1886) & & + & + \\
\hline \multicolumn{4}{|l|}{ Mytilidae } \\
\hline Lioberus castaneus (Say, 1822) & & & + \\
\hline \multicolumn{4}{|l|}{ Lucinidae } \\
\hline Codakia costata (Orbigny, 1842) & + & + & + \\
\hline Codakia orbiculata (Montagu, 1808) & & & + \\
\hline Lucina pectinata (Gmelin, 1791) & + & & \\
\hline Divaricella quadrisulcata (Orbigny, 1842) & + & & + \\
\hline \multicolumn{4}{|l|}{ Ungulinidae } \\
\hline Diplodonta punctata (Say, 1822) & + & + & + \\
\hline Phlyctiderma semiaspera (Philippi,1836) & & & + \\
\hline \multicolumn{4}{|l|}{ Cardiidae } \\
\hline Trachycardium muricatum (Linnaeus, 1758) & & & + \\
\hline Laevicardium laevigatum (Linnaeus, 1758) & & & + \\
\hline \multicolumn{4}{|l|}{ Mactridae } \\
\hline Mactra fragilis Gmelin, 1791 & & & + \\
\hline Mulinia cleryana (Orbigny, 1846) & & + & \\
\hline \multicolumn{4}{|l|}{ Solenidae } \\
\hline Solen tehuelchus Orbigny, 1843 & & + & + \\
\hline
\end{tabular}


Tabela I. Continuação.

\begin{tabular}{|c|c|c|c|}
\hline Espécies & Barra Velha & Perequê & Engenho D'água \\
\hline \multicolumn{4}{|l|}{ Tellinidae } \\
\hline Tellina (Eurytellina) lineata Turton, 1819 & + & & \\
\hline Tellina (Eurytellina) punicea Born, 1778 & + & & \\
\hline Tellina (Angulus) versicolor De Kay, 1843 & + & + & + \\
\hline Strigilla (Strigilla) carnaria (Linnaeus, 1758) & + & & \\
\hline Macoma cleryana (Orbigny, 1846) & + & & + \\
\hline Macoma constricta (Bruguière, 1792) & + & & \\
\hline Macoma uruguayensis (E.A. Smith, 1885) & + & & \\
\hline \multicolumn{4}{|l|}{ Semelidae } \\
\hline Semele proficua (Pulteney, 1799) & & & + \\
\hline Semele purpurascens (Gmelin, 1791) & & & + \\
\hline Abra lioica (Dall, 1881) & & + & \\
\hline Ervilia nitens (Montagu, 1806) & & + & + \\
\hline \multicolumn{4}{|l|}{ Solecurtidae } \\
\hline Tagelus plebeius (Lightfoot, 1786) & + & & \\
\hline Tagelus divisus (Spengler, 1794) & + & + & + \\
\hline \multicolumn{4}{|l|}{ Veneridae } \\
\hline Chione subrostrata (Lamarck, 1818) & + & + & + \\
\hline Chione cancellata (Linnaeus, 1767) & + & + & \\
\hline Chione intapurpurea (Conrad, 1849) & & & + \\
\hline Anomalocardia brasiliana (Gmelin, 1791) & + & & + \\
\hline Transennella stimpsoni Dall, 1902 & & & + \\
\hline Gouldia cerina (C.B. Adams, 1845) & & & + \\
\hline Pitar fulminatus (Menke, 1828) & & + & + \\
\hline Pitar palmen Fischer-Piette \& Testud, 1967 & & & + \\
\hline \multicolumn{4}{|l|}{ Corbulidae } \\
\hline Corbula caribaea Orbigny, 1842 & + & & + \\
\hline Corbula cubaniana Orbigny, 1853 & & + & + \\
\hline \multicolumn{4}{|l|}{ Thraciidae } \\
\hline Thracia similis Couthony, 1839 & & + & + \\
\hline
\end{tabular}

\section{Gastropoda}

As famílias de Gastropoda ocorrentes nos pontos estudados são caracterizadas na tabela II.

\section{Caracterização das espécies}

\section{Trochidae}

Calliostoma adspersum (Philippi, 1851). Concha (até 20,5 mm de comprimento) com voltas de perfil plano e quilha fraca, periférica. Superfície esculturada por numerosos cordões espirais finamente nodulosos, mais conspícuos na periferia das últimas voltas. Coloração branca-suja a amarelada, com manchas irregulares de cor marrom avermelhada. Abertura arredondada, sem estrias ou dentes. Área umbilical imperfurada, rasa e iridescente. Detritívoros e herbivoros.

Distribuição. Norte da Colômbia, Suriname, Brasil (nordeste ao sul). Fundos lodosos e arenosos, da região entremarés até $25 \mathrm{~m}$ de profundidade.

Tegula viridula (Gmelin, 1791). Concha globosa (até $19 \mathrm{~mm}$ de comprimento x $23 \mathrm{~mm}$ no maior diâmetro), com perfil das voltas convexo. Superfície ornamentada com 7 cordões espirais nodulosos entre a sutura e a periferia, e 6 na base (estes lisos ou nodulosos). Abertura semicircular; columela arqueada, com 3 a 4 dentes pequenos. Umbílico circular, profundo e funiculado. Herbívoros.

Distribuição. Costa leste do Panamá, Venezuela, Suriname, Brasil (Ceará a Santa Catarina). Espécie comum em rochas na zona entremarés. 
Tabela II. Caracterização das familias de Gastropoda.

\begin{tabular}{|c|c|c|c|c|c|c|}
\hline \multirow{2}{*}{ Familias } & \multicolumn{4}{|c|}{ Concha } & \multirow{2}{*}{ Opérculo } & \multirow{2}{*}{$\begin{array}{c}\text { Outras } \\
\text { características }\end{array}$} \\
\hline & Formato & Ornamentaçăo & Canal sifonal & Umbílico & & \\
\hline $\begin{array}{l}\text { Trochidae } \\
\text { (Fig. 1) }\end{array}$ & $\begin{array}{l}\text { Trocóide ou } \\
\text { globosa }\end{array}$ & $\begin{array}{l}\text { Variável, } \\
\text { geralmente } \\
\text { com costelas } \\
\text { espirais } \\
\text { nodulosas }\end{array}$ & Ausente & $\begin{array}{l}\text { Imperfurado ou } \\
\text { năo }\end{array}$ & $\begin{array}{l}\text { Corneo, } \\
\text { multiespiral }\end{array}$ & $\begin{array}{l}\text { Camada interna } \\
\text { nacarada; dente na } \\
\text { base da columela } \\
\text { ausente }\end{array}$ \\
\hline $\begin{array}{l}\text { Phenacolepadidae } \\
\text { (Fig. 2) }\end{array}$ & $\begin{array}{l}\text { Cônica (em } \\
\text { forma de lapa) }\end{array}$ & $\begin{array}{l}\text { Ausente ou } \\
\text { radial }\end{array}$ & Ausente & Ausente & Ausente & $\begin{array}{l}\text { Apice voltado para a } \\
\text { margem posterior }\end{array}$ \\
\hline $\begin{array}{l}\text { Modulidae } \\
\text { (Fig. 3) }\end{array}$ & Trocóide & $\begin{array}{l}\text { Geralmente } \\
\text { com cordas } \\
\text { espirais } \\
\text { nodulosas }\end{array}$ & Ausente & $\begin{array}{l}\text { Estreito, } \\
\text { raramente } \\
\text { imperfurado }\end{array}$ & $\begin{array}{l}\text { Córneo, } \\
\text { circular, } \\
\text { multiespiral }\end{array}$ & $\begin{array}{l}\text { Dente pequeno, } \\
\text { conspicuo, } \\
\text { projetando-se da } \\
\text { base da columela }\end{array}$ \\
\hline $\begin{array}{l}\text { Cerithiidae } \\
\text { (Fig. 4) }\end{array}$ & $\begin{array}{l}\text { Alongada, } \\
\text { Turriforme }\end{array}$ & $\begin{array}{l}\text { Cordas espirais } \\
\text { nodulosas }\end{array}$ & $\begin{array}{l}\text { Curto, } \\
\text { geralmente } \\
\text { recurvado }\end{array}$ & Imperfurado & $\begin{array}{l}\text { Córneo (fino). } \\
\text { paucispiral }\end{array}$ & \\
\hline $\begin{array}{l}\text { Naticidae } \\
\text { (Fig. 5) }\end{array}$ & $\begin{array}{l}\text { Globosa ou } \\
\text { fortemente } \\
\text { deprimida }\end{array}$ & Ausente & Ausente & $\begin{array}{l}\text { Profundo ou } \\
\text { funiculado }\end{array}$ & $\begin{array}{l}\text { Córneo ou } \\
\text { calcário, } \\
\text { paucispiral }\end{array}$ & $\begin{array}{l}\text { Espira baixa, volta } \\
\text { do corpo grande; } \\
\text { forte calosidade no } \\
\text { lábio parietal }\end{array}$ \\
\hline $\begin{array}{l}\text { Muricidae } \\
\text { (Fig. 6) }\end{array}$ & Variável & Variável & $\begin{array}{l}\text { Geralmente } \\
\text { tubular (bem } \\
\text { desenvolvido) }\end{array}$ & Ausente & $\begin{array}{l}\text { Córneo, } \\
\text { ungüiforme-alon- } \\
\text { gado }\end{array}$ & \\
\hline $\begin{array}{l}\text { Nassariidae } \\
\text { (Fig. 7) }\end{array}$ & Ovalada & $\begin{array}{l}\text { Tendendo a } \\
\text { cancelada }\end{array}$ & $\begin{array}{l}\text { Curto, } \\
\text { recurvado }\end{array}$ & Ausente & $\begin{array}{l}\text { Córneo, oval } \\
\text { (núcleo apical) }\end{array}$ & $\begin{array}{l}\text { Lábio externo } \\
\text { estriado } \\
\text { internamente; base } \\
\text { da abertura com } \\
\text { entalhe profundo }\end{array}$ \\
\hline $\begin{array}{l}\text { Fasciolariidae } \\
\text { (Fig. } 8 \text { ) }\end{array}$ & $\begin{array}{l}\text { Oval-fusiforme } \\
\text { a fusiforme }\end{array}$ & $\begin{array}{l}\text { Costelas axiais } \\
\text { frequentemente } \\
\text { nodulosas e } \\
\text { linhas espirais }\end{array}$ & Desenvolvido & Ausente & $\begin{array}{l}\text { Córneo } \\
\text { (desenvolvido) } \\
\text { ungüiforme }\end{array}$ & $\begin{array}{l}\text { Columela com } \\
\text { poucas pregas } \\
\text { espirais fracas; face } \\
\text { interna do lábio } \\
\text { externo com } \\
\text { numerosas estrias } \\
\text { alongadas }\end{array}$ \\
\hline $\begin{array}{l}\text { Olividae } \\
\text { (Fig. 9) }\end{array}$ & $\begin{array}{l}\text { Obovada, } \\
\text { obcónica ou } \\
\text { cilindrica }\end{array}$ & Ausente & Ausente & Ausente & $\begin{array}{l}\text { Pequeno ou } \\
\text { ausente }\end{array}$ & $\begin{array}{l}\text { Porcelanácea, } \\
\text { polida, brilhante, } \\
\text { sem periostraco; } \\
\text { abertura estreita, às } \\
\text { vezes quase tăo } \\
\text { longa quanto a } \\
\text { concha; columela } \\
\text { geralmente com } \\
\text { pregas lamelares } \\
\text { fortes; sutura } \\
\text { fortemente } \\
\text { canaliculada }\end{array}$ \\
\hline $\begin{array}{l}\text { Bullidae } \\
\text { (Fig. 10) }\end{array}$ & Oval a globular & Ausente & Ausente & Profundo & Ausente & $\begin{array}{l}\text { Fina, leve; espira } \\
\text { baixa ou } \\
\text { aprofundada; } \\
\text { abertura ampla, tão } \\
\text { longa ou maior que o } \\
\text { comprimento da } \\
\text { concha; calo } \\
\text { presente na } \\
\text { columela; o animal } \\
\text { năo se retrai } \\
\text { completamente }\end{array}$ \\
\hline
\end{tabular}




\section{Phenacolepadidae}

Phenacolepas hamillei (Fischer, 1857). Concha frágil (até $8 \times 6 \mathrm{~mm}$ ). Região nuclear diminuta, espiralada, semi-imersa. Esculturação constituída por muitas costelas radiais (cerca de 60) com espinhos diminutos, e cruzadas por numerosas linhas concêntricas, formando um padrão cancelado. Cicatriz muscular em forma ferradura. Opérculo ausente.

Distribuição. Estados Unidos (Flórida ao Texas), Bermuda, Pequenas Antilhas, Brasil (Alagoas a Santa Catarina). Sob rochas na zona entremarés.

\section{Modulidae}

Modulus modulus (Linnaeus, 1758). Concha com espira baixa (até $12 \times 15$ $\mathrm{mm}$ ). Ornamentação constituída por costelas radiais oblíquas, baixas, cruzadas por cordões espirais fracos. Base com 4 a 5 cordões espirais conspícuos, o da periferia e seu adjacente com nodulosidade evidente. Abertura circular; dente projetando-se da base da columela freqüentemente acastanhado. Concha de cor cinza esbranquiçada. Espécimes com concha desgastada exibem freqüentemente manchas de cor marrom-purpúrea.

Distribuição. Estados Unidos (Carolina do Norte, Flórida e Texas), Índias Ocidentais, Norte da Colômbia, Venezuela, Brasil (Pará a Santa Catarina, Ilha Santa Helena e Abrolhos). Entre gramíneas marinhas, em fundos lodosos na região entremarés e em raízes aéreas de plantas de mangue.

\section{Cerithiidae}

Cerithium atratum (Born, 1778). Concha com 10 a 13 voltas (até $34 \times 13$ $\mathrm{mm}$ ). Ornamentação constituída por quatro a cinco cordões espirais nodulosos (18 a 20 nódulos por volta), entre os quais intercalam-se linhas espirais finamente granulosas. Coloração esbranquiçada, cinza ou creme, com manchas de cor marrom-avermelhada. Umbílico imperfurado, lábio externo crenulado, columela com forte calosidade.

Distribuição. Estados Unidos (Carolina do Norte à Flórida e Texas), Bahamas, Golfo do México, Índias Ocidentais, Norte da Colômbia, Venezuela, Brasil (Ceará a Santa Catarina; ilhas Fernando de Noronha e Martin Vaz). Oeste da África (Serra Leone a Angola; Ilhas Canárias). Em fundos arenosos e lodosos.

Bittium varium (Pfeiffer, 1840). Concha muito pequena (até $3,5 \mathrm{~mm}$ de comprimento), sete a oito voltas de perfil convexo. Ornamentação constituída por costelas axiais, ligeiramente inclinadas, cruzadas e sobrepostas por cordões espirais (quatro a cinco por volta), resultando num padrão cancelado, com nódulos alongados nas intersecções. Volta do corpo com uma varize oblíqua, acentuada e esbranquiçada. Base com cordões espirais finos e lisos.

Distribuição. Estados Unidos (Carolina do Norte a Flórida e Texas), Índias Ocidentais, Brasil (todo litoral). Em águas rasas, entre algas e gramíneas marinhas.

Naticidae

Polinices lacteus (Guilding, 1834). Concha de cor branca (até 30×20mm), polida, com perióstraco fino, liso, amarelado a marrom. Umbílico profundo com abertura parcialmente obliterada pela forte calosidade do lábio parietal. Opérculo quitinoso, fino, em forma de "D" e avermelhado. Predador de bivalves. 

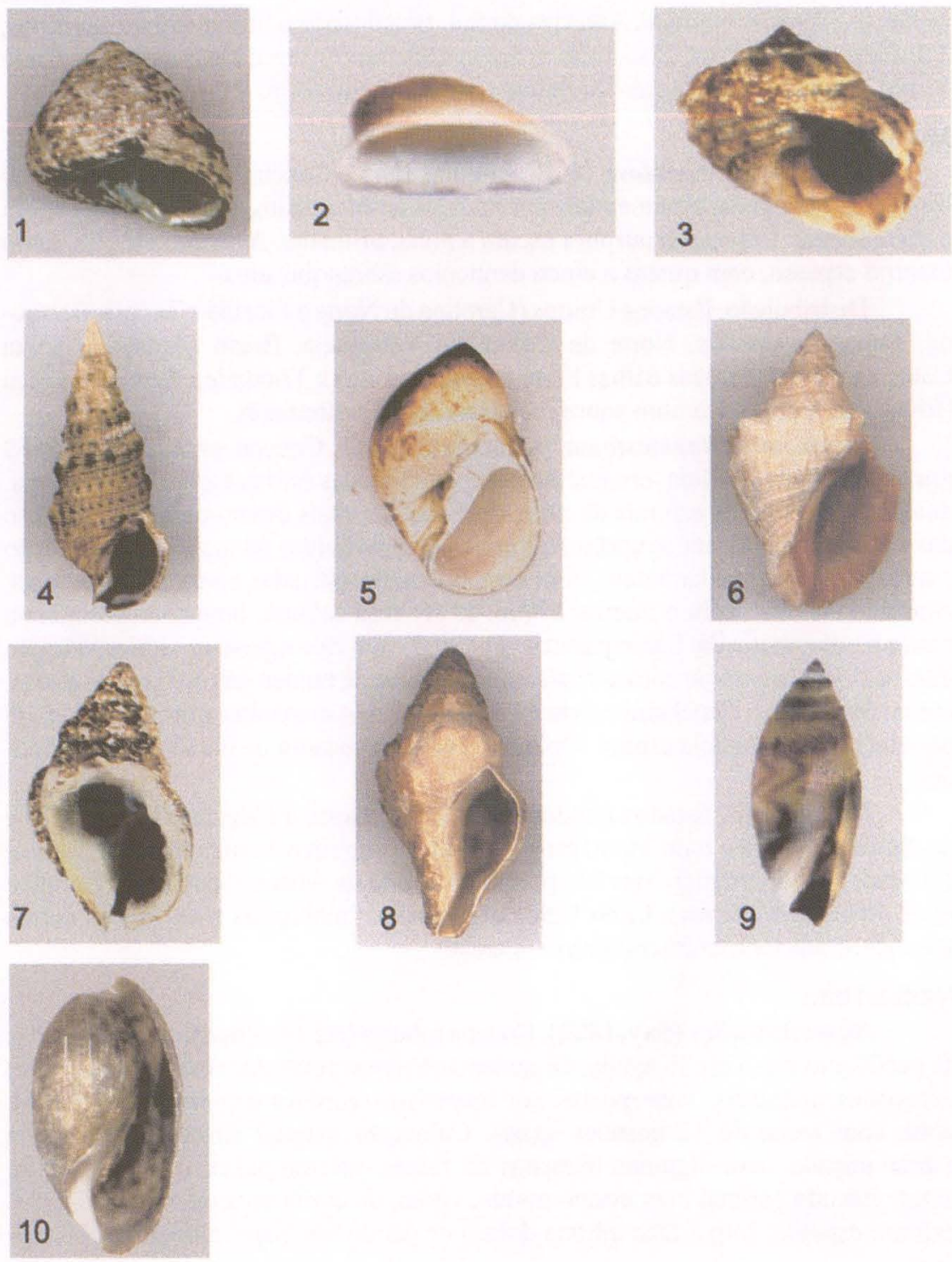

Figs 1-10. Gastropoda. (1) Trochidae, Tegula viridula; (2) Phenacolepadidae, Phenacolepas hamillei; (3) Modulidae, Modulus modulus; (4) Cerithiidae, Cerithium varium; (5) Naticidae, Polinices lacteus; (6) Muricidae, Stramonita haemastoma; (7) Nassariidae, Nassarius vibex; (8) Fasciolariidae, Leucozonia nassa; (9) Olividae, Olivella minuta; (10) Bullidae, Bulla striata. 
Distribuição. Estados Unidos (Carolina do Norte a Flórida), Cuba, Bermuda, Índias Ocidentais, Norte da América do Sul, Brasil (todo o litoral e ilhas Abrolhos, Trindade, Martin Vaz, Ascensão e Santa Helena). Oeste da África (ilhas Cabo Verde, Canárias e Madeira). Da região entremarés até $60 \mathrm{~m}$.

\section{Muricidae}

Trachypolia nodulosa (C.B. Adams, 1845). Concha pequena (até $18 \times 10$ $\mathrm{mm}$ ), oval-alongada, ornamentada por nódulos arredondados, alinhados em espiral e radialmente. Coloração púrpura escura a preta, brilhante. Abertura estreita, lábio externo espesso, com quatro a cinco dentículos esbranquiçados.

Distribuição. Estados Unidos (Carolina do Norte a Flórida e Texas), Bermuda, Índias Ocidentais, Norte da Colômbia, Venezuela, Brasil (Amapá a Santa Catarina, Atol das Rocas e ilhas Fernando de Noronha e Trindade). Oeste da África (Ilha Cabo Verde). Comum sobre rochas na região entremarés.

Stramomita haemastoma (Linnaeus, 1767). Concha grande (até $75 \times 52$ $\mathrm{mm}$ ), polimórfica, sólida, ornamentada com numerosas estrias espirais finas e uma, duas ou mais fileiras espirais de nódulos. Estes são mais desenvolvidos no ombro das voltas, onde podem se apresentar pouco desenvolvidos ou ausentes. Coloração externa cinza clara a caramelo, com ou sem bandas estriadas ou manchas escuras. Abertura suboval, com o interior vítreo, de cor rosa-salmon, branca-amarelada ou castanha-avermelhada. Lábio parietal coberto por um calo espesso e vítreo. Margem interna do lábio externo caracteristicamente dotada de numerosas estrias alongadas, creme ou brancas. Canal sifonal curto, canal anal bem marcado e margeado no lado parietal por uma costela espiral. Opérculo córneo. Predador de bivalves e gastrópodes.

Distribuição. Estados Unidos (Carolina do Norte a Flórida e Texas), Norte da América do Sul e todo litoral brasileiro (incluindo ilhas Fernando de Noronha e Trindade) até o Uruguai, Mar Mediterrâneo, Oeste da África (Senegal ao Congo e ilhas Madeira, Canárias e Cabo Verde). Comum em ambientes rochosos, podendo ser encontrada temporariamente sobre areia.

\section{Nassariidae}

Nassarius vibex (Say, 1822). Concha robusta (até $14 \times 8 \mathrm{~mm}$ ), com sete voltas de perfil convexo e espira aguda. Ornamentação constituída por costelas axiais com expansões nodulares, sobrepostas por numerosos cordões espirais finos; última volta com cerca de 12 costelas axiais. Coloração externa cinza-acastanhada a esbranquiçada, com algumas manchas ou faixas interrompidas, de cor marrom, tênue. Escudo parietal bem desenvolvido, vítreo, de cor branca ou amarela. Lábio externo espesso, com a face interna dotada de dentes lamelares alongados. Necrófago.

Distribuição. Estados Unidos (Cabo Cod a Flórida), Índias Ocidentais, Venezuela, Brasil (Pará a Santa Catarina). Em baixios arenosos, lodosos e águas salobras.

\section{Fasciolariidae}

Leucozonia nassa (Gmelin, 1791). Concha grande (até 60x30 mm), polimórfica, robusta, com voltas de ombro anguloso, dotado de aproximadamente nove 
nódulos grandes por volta. Superfície ornamentada por numerosos cordões espirais estreitos, intercalados por cordões mais finos. Coloração marrom clara a escura, semi-polida, com uma faixa branca estreita (nem sempre distinta ou presente), na base da concha e terminando em um espinho na margem do lábio externo. Base da columela com três a quatro pregas espirais, sendo a quarta prega, quando presente, pouco conspícua. Canal sifonal pouco extenso. Predador de outros gastrópodes e bivalves. Vive no mesmo habitat de Stramonita haemastoma, com a qual se confunde pelo aspecto da concha. O corpo de cor vermelha alaranjada ou púrpura viva de Leucozonia facilita a distinção.

Distribuição. Estados Unidos (Flórida e Texas), Índias Ocidentais, Norte da Colômbia, Venezuela, Brasil (Ceará a Santa Catarina; Atol das Rocas e ilhas Fernando de Noronha e Trindade). Comum sobre rochas.

\section{Olividae}

Olivella minuta (Link, 1807). Concha pequena (até $15 \mathrm{~mm}$ de comprimento), globosa, com sutura sulcada e aberta. Coloração variável, geralmente cinza-clara, marrom ou esverdeada, com linhas marrons ou purpúreas em zigzag na volta do corpo. Fascíola ampla, esbranquiçada, com uma faixa mediana de cor marrom. Calo parietal forte, estendendo-se além do ângulo posterior da abertura, em direção à linha de sutura.

Distribuição. Estados Unidos (Texas), Índias Ocidentais, Norte da Colômbia, Venezuela, Suriname, Brasil (Ceará a Santa Catarina). Fundos arenosos de regiões entremarés.

\section{Bullidae}

Bulla striata Bruguière, 1792. Concha cilíndrica-ovalada (até $39 \mathrm{~mm}$ de comprimento e $16 \mathrm{~mm}$ no maior diâmetro), com porção apical de menor diâmetro que a basal e espira aprofundada. Superfície externa com linhas de crescimento, e geralmente com linhas espirais próximas à base e no interior da cavidade apical. Coloração creme, marrom-clara a cinza-esverdeada escura, com manchas irregulares de tons marrom-claro a preto. Abertura alta e estreita na região apical, ampla e ovalada na ventral. Superficie interna e calo parietal de cor branca; calo geralmente com mancha marrom. Carnívora.

Distribuição. Estados Unidos (Carolina do Norte ao Texas), Bermuda, Índias Ocidentais, Venezuela, Brasil (toda costa brasileira, inclusive Ilha Santa Helena). Mar Mediterrâneo, Portugal, Marrocos. Substratos areno-lodosos, no infralitoral e níveis inferiores da região entremarés.

\section{Polyplacophora}

\section{Ischnochitonidae}

Ischnochiton striolatus (Gray, 1828). Corpo oblongo, moderadamente arqueado (até $15 \mathrm{~mm}$ de comprimento $\times 8 \mathrm{~mm}$ de largura). Placas com colorido variável, do verde-oliva ao creme, com ou sem manchas róseas, alaranjadas, azuis, marrons, pretas. Placas cefálica e caudal ornamentadas com estrias em zigzag, concêntricas; placas intermediárias com áreas laterais ornamentadas longitudinalmente com estrias finas em zigzag e área central com granulação fina. Mucro elevado, central e côncavo posteriormente. Cinturão com escamas imbricadas, mais 
ou menos largas, curvadas e costeladas, coloridas com manchas róseas ou azuis esverdeadas. Margem do perinoto com longos espinhos de bainha simples, e entre eles, espinhos menores; face inferior do perinoto recoberta por placas retangulares, alongadas, arranjadas em filas transversais.

Distribuição. Estados Unidos (Flórida), Índias Ocidentais, Brasil (Amapá a Santa Catarina). Sobre rochas entremarés e corais.

\section{Bivalvia}

As famílias de Bivalvia ocorrentes nos pontos estudados são caracterizadas na tabelas III e IV.

Tabela III. Caracterização das famílias de Bivalvia.

\begin{tabular}{|c|c|c|c|}
\hline Familias & Concha & Ornamentaçăo & Ligamento \\
\hline $\begin{array}{l}\text { Arcidae } \\
\text { (Fig. 11) }\end{array}$ & $\begin{array}{l}\text { Geralmente eqüivalve, } \\
\text { inequilateral, subtrapezoidal, } \\
\text { retangular a ovalada }\end{array}$ & $\begin{array}{l}\text { Costelada ou reticulada; } \\
\text { perióstraco fibroso ou aveludado }\end{array}$ & Duplivincular \\
\hline $\begin{array}{l}\text { Mytilidae } \\
\text { (Fig. 12) }\end{array}$ & $\begin{array}{l}\text { Alongada a cuneiforme, eqüivalve, } \\
\text { inequilateral }\end{array}$ & $\begin{array}{l}\text { Ausente ou radial; perióstraco às } \\
\text { vezes piloso }\end{array}$ & Longo, interno \\
\hline $\begin{array}{l}\text { Lucinidae } \\
\text { (Fig. 13) }\end{array}$ & $\begin{array}{l}\text { Suborbicular ou ovalada, } \\
\text { comprimida }\end{array}$ & Variável & Externo ou parcialmente interno. \\
\hline $\begin{array}{l}\text { Ungulinidae } \\
\text { (Fig. 14) }\end{array}$ & $\begin{array}{l}\text { Subtrigonal, oblonga ou } \\
\text { subcircular; geralmente inflada }\end{array}$ & $\begin{array}{l}\text { Ausente, apenas com linhas de } \\
\text { crescimento ou pustulada }\end{array}$ & Externo \\
\hline $\begin{array}{l}\text { Cardiidae } \\
\text { (Fig. 15) }\end{array}$ & $\begin{array}{l}\text { Trigonal-arredondada, cordiforme, } \\
\text { eqüivalve }\end{array}$ & Radial geralmente forte & Externo, curto \\
\hline $\begin{array}{l}\text { Mactridae } \\
\text { (Fig. 16) }\end{array}$ & $\begin{array}{l}\text { Subtrigonal arredondada a } \\
\text { ovalada, eqüivalve, fina (mas forte), } \\
\text { porcelanácea }\end{array}$ & Ausente ou concêntrica & $\begin{array}{l}\text { Externo e com porção interna } \\
\text { alojada no condróforo }\end{array}$ \\
\hline $\begin{array}{l}\text { Solenidae } \\
\text { (Fig. 17) }\end{array}$ & $\begin{array}{l}\text { Muito alongada, em geral cilíndrica, } \\
\text { comprimida, truncada e aberta nas } \\
\text { extremidades }\end{array}$ & Ausente, perióstraco brilhante & Externo \\
\hline $\begin{array}{l}\text { Tellinidae } \\
\text { (Fig. 18) }\end{array}$ & $\begin{array}{l}\text { Circular a oval alongada, } \\
\text { inequilateral; moderadamente } \\
\text { comprimida; fina }\end{array}$ & Geralmente concêntrica & Externo \\
\hline $\begin{array}{l}\text { Semelidae } \\
\text { (Fig. 19) }\end{array}$ & $\begin{array}{l}\text { Oval a arredondada, } \\
\text { moderadamente convexa }\end{array}$ & Ausente ou concêntrica & $\begin{array}{l}\text { Opistodético, a maior parte interna, } \\
\text { inserida no resilffero }\end{array}$ \\
\hline $\begin{array}{l}\text { Solecurtidae } \\
\text { (Fig. 20) }\end{array}$ & $\begin{array}{l}\text { Retangular-alongada, } \\
\text { moderadamente comprimida, } \\
\text { extremidades truncadas }\end{array}$ & $\begin{array}{l}\text { Ausente ou obliqua, cruzando as } \\
\text { linhas de crescimento }\end{array}$ & $\begin{array}{l}\text { Externo, alojado em uma longa } \\
\text { ninfa }\end{array}$ \\
\hline $\begin{array}{l}\text { Veneridae } \\
\text { (Fig. 21) }\end{array}$ & $\begin{array}{l}\text { Suborbicular a oval, cordiforme ou } \\
\text { subtrigonal, equivivalve, } \\
\text { inequilateral, porcelanácea, polida, } \\
\text { forte }\end{array}$ & $\begin{array}{l}\text { Ausente ou radial, concêntrica ou } \\
\text { ambas }\end{array}$ & $\begin{array}{l}\text { Externo, alongado ou curto, em } \\
\text { uma ninfa }\end{array}$ \\
\hline $\begin{array}{l}\text { Corbulidae } \\
\text { (Fig. 22) }\end{array}$ & $\begin{array}{l}\text { Oval-alongada, sub-quadrada ou } \\
\text { trigonal; inflada; pequena, } \\
\text { assimétrica, Ineqüivalve; } \\
\text { moderadamente fina a solida }\end{array}$ & $\begin{array}{l}\text { Geralmente com costelas } \\
\text { concèntricas fortes }\end{array}$ & $\begin{array}{l}\text { Interno, ligado ao resilifero na valva } \\
\text { esquerda }\end{array}$ \\
\hline Thraciidae & $\begin{array}{l}\text { Oval-oblonga a trapezoidal, } \\
\text { inequilateral, porcelanácea, frágil }\end{array}$ & Ausente ou granular & $\begin{array}{l}\text { Predominantemente interno, } \\
\text { litodesma por vezes presente; } \\
\text { condróforo estreito }\end{array}$ \\
\hline
\end{tabular}

\section{Caracterização das espécies}

\section{Arcidae}

Lunarca ovalis (Bruguière, 1789). Concha espessa (até $40 \mathrm{~mm}$ de comprimento) ovalada, subeqüivalve, com a margem da valva esquerda sobrepondo-se à da direita. Ornamentação constituída por 26 a 36 costelas radiais lisas; coloração básica branca, oculta sob um perióstraco marrom escuro a esverdeado, piloso e deiscente. Umbos quase se tocando, geralmente desgastados por se atritarem. Ligamento opistodético; charneira arqueada com a série de dentes anteriores curta 

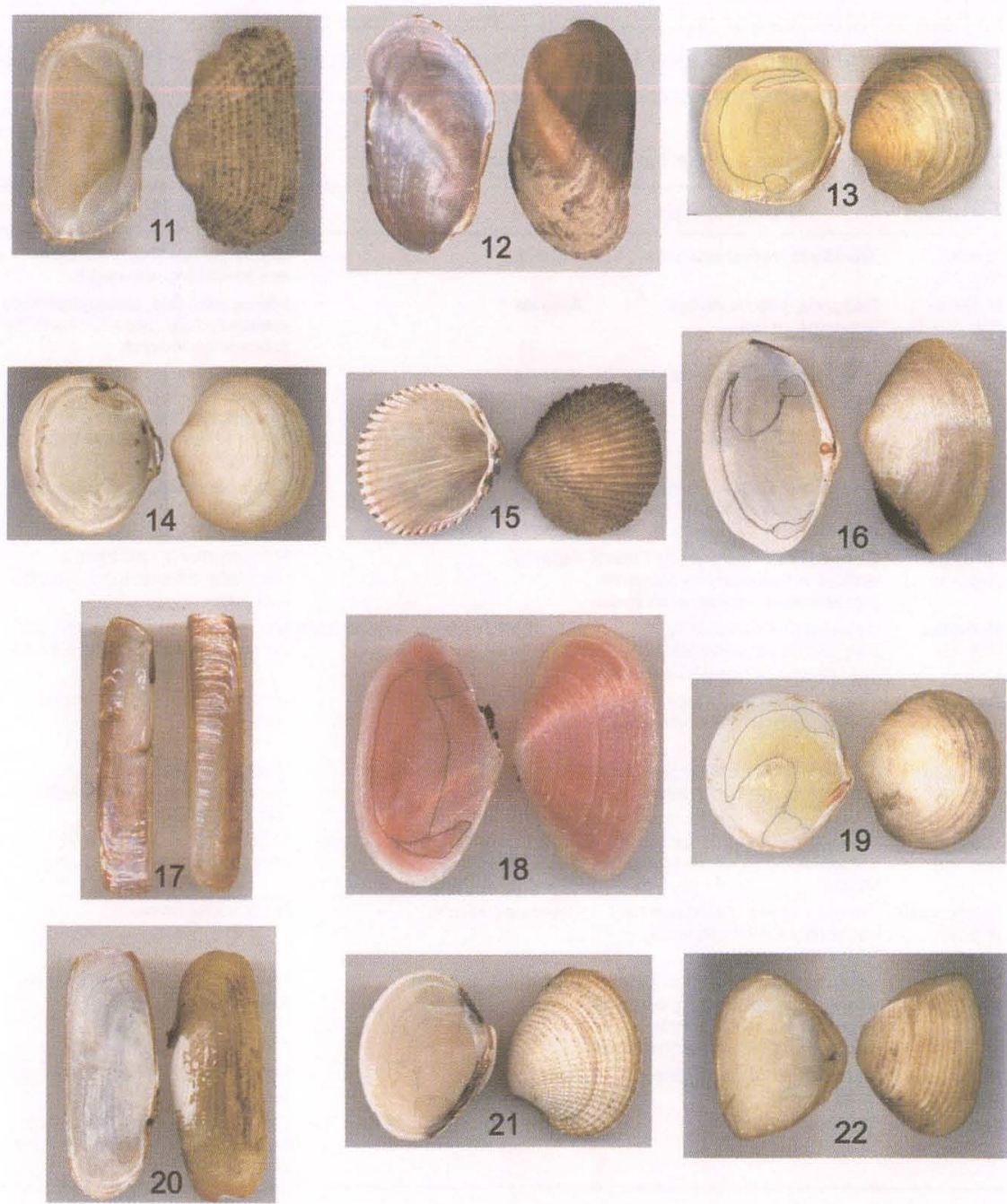

Figs 11-22. Bivalvia. (11) Farcidae, Arcopsis adamsi; (12) Mytilidae, Lioberus castaneus; (13) Lucinidae, Lucina pectinata; (14) Ungulinidae, Diplodonta punctata; (15) Cardiidae, Trachycardium muricatum; (16) Mactridae, Mactra fragilis; (17) Solenidae, Solen tehuelchus; (18) Tellinidae, Tellina punicea; (19) Semelidae, Semele proficua; (20) Solecurtidae, Tagelus plebeius; (21) Veneridae, Chione subrostrata; (22) Corbulidae, Corbula caribaea. Quando necessário foram demarcadas as linhas de inserção muscular e do manto. 
e dentes dispostos irregularmente, e série posterior longa, com dentes dispostos regularmente. Margem livre crenulada e periferia da margem interna com costelas radiais, resultantes dos sulcos entre as costelas na face externa.

Distribuição. Estados Unidos (Carolina do Norte a Flórida e Texas), Índias Ocidentais, Venezuela, Brasil ao Uruguai. Sob rochas e corais.

Tabela IV.Caracterização das famílias de Bivalvia.

\begin{tabular}{|c|c|c|c|}
\hline Familias & Charneira/Dentes & Seio palial & Outras características \\
\hline $\begin{array}{l}\text { Arcidae } \\
\text { (Fig. 11) }\end{array}$ & Taxodonte reta ou arqueada & Ausente & $\begin{array}{l}\text { Interior porcelanáceo, cicatrizes } \\
\text { dos adutores quase iguais }\end{array}$ \\
\hline $\begin{array}{l}\text { Mytilidae } \\
\text { (Fig. 12) }\end{array}$ & $\begin{array}{l}\text { Reduzida, poucos dentes } \\
\text { diminutos ou lisa }\end{array}$ & Ausente & $\begin{array}{l}\text { Interior nacarado; bisso geralmente } \\
\text { presente; cicatriz do adutor anterior } \\
\text { pequena ou ausente }\end{array}$ \\
\hline $\begin{array}{l}\text { Lucinidae } \\
\text { (Fig. 13) }\end{array}$ & $\begin{array}{l}2 \text { ou } 3 \text { cardinais em cada valva; } 0 \text {, } \\
1 \text { ou } 2 \text { laterais }\end{array}$ & Ausente & $\begin{array}{l}\text { Umbos baixos e quase centrais: } \\
\text { margem interna das valvas } \\
\text { geralmente crenulada; cicatriz do } \\
\text { adutor anterior longa e estreita, do } \\
\text { posterior, menor e arredondada }\end{array}$ \\
\hline $\begin{array}{l}\text { Ungulinidae } \\
\text { (Fig. 14) }\end{array}$ & $\begin{array}{l}2 \text { cardinais ( } 1 \text { bifido em cada } \\
\text { valva); laterais obsoletos ou } \\
\text { ausentes }\end{array}$ & Ausente & $\begin{array}{l}\text { Cicatrizes dos adutores grandes e } \\
\text { subiguais }\end{array}$ \\
\hline $\begin{array}{l}\text { Cardiidae } \\
\text { (Fig. 15) }\end{array}$ & $\begin{array}{l}2 \text { cardinais em cada valva; } 1 \text { lateral } \\
\text { anterior e } 1 \text { posterior na esquerda, } \\
2 \text { anteriores e } 1 \text { posterior na direita }\end{array}$ & Ausente & $\begin{array}{l}\text { Margem interna serrilhada a } \\
\text { crenulada; cicatrizes dos adutores } \\
\text { subiguais }\end{array}$ \\
\hline $\begin{array}{l}\text { Mactridae } \\
\text { (Fig. 16) }\end{array}$ & $\begin{array}{l}1 \text { cardinal em forma de " } V \text { " } \\
\text { invertido na valva esquerda, } 2 \\
\text { cardinais na direita; vários laterais }\end{array}$ & Geralmente profundo, arredondado & $\begin{array}{l}\text { Margem dorsal posterior limitada } \\
\text { por uma costela ou quilha elevada }\end{array}$ \\
\hline $\begin{array}{l}\text { Solenidae } \\
\text { (Fig. 17) }\end{array}$ & $\begin{array}{l}\text { Fraca: } 1 \text { cardinal em cada valva; } \\
\text { laterais, quando presentes, fracos } \\
\text { e finos }\end{array}$ & Geralmente raso & $\begin{array}{l}\text { Umbos na extremidade anterior, } \\
\text { reduzidos }\end{array}$ \\
\hline $\begin{array}{l}\text { Tellinidae } \\
\text { (Fig. 18) }\end{array}$ & $\begin{array}{l}2 \text { cardinais ( } 1 \text { bifido) pequenos em } \\
\text { cada valva; } 0,1 \text { ou } 2 \text { laterais }\end{array}$ & Grande e profundo & $\begin{array}{l}\text { Coloração variável, } \\
\text { frequentemente brilhante; umbos } \\
\text { baixos e pequenos }\end{array}$ \\
\hline $\begin{array}{l}\text { Semelidae } \\
\text { (Fig. 19) }\end{array}$ & $\begin{array}{l}\text { Variável: cardinais quase sempre } \\
\text { presentes e laterais em ambas as } \\
\text { valvas }\end{array}$ & $\begin{array}{l}\text { Profundo e amplamente } \\
\text { arredondado }\end{array}$ & $\begin{array}{l}\text { Geralmente com leve flexão } \\
\text { posterior }\end{array}$ \\
\hline $\begin{array}{l}\text { Solecurtidae } \\
\text { (Fig. 20) }\end{array}$ & $\begin{array}{l}\text { Fraca e estreita, } 2 \text { cardinais na } \\
\text { valva direita, } 1 \text { na esquerda, } \\
\text { laterais ausentes }\end{array}$ & Grande e profundo & Umbos subcentrais \\
\hline $\begin{array}{l}\text { Veneridae } \\
\text { (Fig. 21) }\end{array}$ & $\begin{array}{l}\text { Complexa: } 3 \text { cardinais em cada } \\
\text { valva ( } 1 \text { ou mais bifidos); lateral na } \\
\text { esquerda e correspondente } \\
\text { encaixe na direita presentes ou não }\end{array}$ & Geralmente profundo & $\begin{array}{l}\text { Umbos submedianos anteriores; } \\
\text { lünula presente }\end{array}$ \\
\hline $\begin{array}{l}\text { Corbulidae } \\
\text { (Fig. 22) }\end{array}$ & $\begin{array}{l}\text { Geralmente } 1 \text { cardinal forte na } \\
\text { valva direita }\end{array}$ & Raso ou ausente & $\begin{array}{l}\text { Valva direita geralmente maior que } \\
\text { a esquerda }\end{array}$ \\
\hline Thraciidae & Edẽntula & Geralmente largo e profundo & $\begin{array}{l}\text { Extremidade posterior levemente } \\
\text { truncada; valva direita maior e mais } \\
\text { convexa que a esquerda }\end{array}$ \\
\hline
\end{tabular}

Arcopsis adamsi (Smith, 1890). Concha sub-retangular (até $17 \mathrm{~mm}$ de comprimento), subequilateral, moderadamente inflada e ornamentada por lamelas concêntricas, cruzadas por numerosas costelas radiais, dotadas de nódulos alongados nas intersecções. Coloração creme, sob perióstraco fino marrom amarelado. Ligamento restrito a uma pequena região triangular entre os umbos. Margens internas lisas.

Distribuição. Estados Unidos (Carolina do Norte a Flórida e Texas), Índias Ocidentais, Venezuela, Brasil (Amapá a Santa Catarina). Sob rochas e corais mortos, da região entremarés até $50 \mathrm{~m}$ de profundidade. 


\section{Mytilidae}

Lioberus castaneus (Say, 1822). Concha oval-alongada (até $11 \mathrm{~mm}$ de comprimento), inflada, fina, de superfície lisa, a não ser pelas linhas de crescimento. Metade anterior marrom, brilhante, bem distinta da posterior, comumente com perióstraco marrom mais claro ou acinzentado, opaco. Charneira simples, sem dentes e com uma ligeira protuberância sob os umbos. Interior branco-azulado, iridescente.

Distribuição. Estados Unidos (Flórida e Texas), Índias Ocidentais, Brasil (Rio de Janeiro a Santa Catarina e Ilha de São Sebastião). Presa a rochas, pedras e conchas mortas, em águas rasas. Espécie de hábito aninhador.

\section{Lucinidae}

Codakia costata (Orbigny, 1842). Concha geralmente orbicular (até $13 \mathrm{~mm}$ de comprimento), inflada, branca-amarelada. Lúnula pequena, aprofundada, lanceolada e ligeiramente maior na valva direita. Ornamentação composta por costelas radiais geralmente aos pares, intercaladas por uma, ou raramente duas costelas mais estreitas, todas cruzadas e sobrepostas por linhas concêntricas finas. Ligamento parcialmente interno.

Distribuição. Estados Unidos (Carolina do Norte a Flórida), Bermuda, Índias Ocidentais, Venezuela, Brasil (Amapá a Santa Catarina). Em fundos arenosos, da região entremarés até $90 \mathrm{~m}$ de profundidade.

Codakia orbiculata (Montagu, 1808). Concha suborbicular (até $23 \mathrm{~mm}$ de comprimento), branca-amarelada. Lúnula alongada, aprofundada e lanceolada. Ornamentação constituída por costelas radiais comumente divaricadas, cruzadas e sobrepostas por linhas concêntricas e conspícuas, formando projeções baixas, lamelares, nas intersecções com as costelas. Ligamento parcialmente interno.

Distribuição. Estados Unidos (Carolina do Norte a Flórida), Bermuda, Índias Ocidentais, Venezuela, Brasil (Ceará a São Paulo). Fundos arenosos, da região entremarés a $180 \mathrm{~m}$ de profundidade.

Lucina pectinata (Gmelin, 1791). Concha subcircular (até $65 \mathrm{~mm}$ de comprimento), sólida, moderadamente inflada e de cor branca-amarelada. Lúnula pequena, quase circular em espécimes pequenos e alongada em espécimes gerônticos, com margem periférica elevada, formando uma lâmina de perfil pouco definido em direção anterior. Superfície externa ornamentada por lamelas concêntricas finas, pouco elevadas, irregularmente espaçadas e mais concentradas e evidentes na área dorsal porterior. Área dorsal posterior com uma quilha que se estende do umbo até a margem posterior. Perióstraco fino e decíduo. Ligamento externo. Dentes laterais e cardinais conspícuos nos jovens, os cardinais fracos a ausentes nos adultos.

Distribuição. Estados Unidos (Carolina do Norte a Flórida e Texas), Índias Ocidentais, Venezuela, Suriname, Brasil (Amapá a Santa Catarina). Fundos arenolodosos em águas rasas.

Divaricella quadrisulcata (Orbigny, 1842). Concha quase circular (até 24 $\mathrm{mm}$ de comprimento), moderadamente inflada, branca-brilhante, com umbos praticamente centrais. Lúnula pequena, mais desenvolvida na valva direita. Superfície externa esculturada por costelas amplas, achatadas, em curvas paralelas, fortemente divaricadas a partir do declive umbonal anterior, com ângulo voltado para o dorso.

Revta bras. Zool. 15 (4): 1013 - 1035, 1998 
Ligamento externo. Dentes cardinais conspícuos e laterais obsoletos. Margem interna finamente crenulada.

Distribuição. Estados Unidos (Carolina do Norte a Flórida), Índias Ocidentais, Venezuela, Brasil (Pará ao norte do Rio Grande do Sul). Em fundos arenosos, da região entremarés até $100 \mathrm{~m}$ de profundidade.

\section{Ungulinidae}

Diplodonta punctata (Say, 1822). Concha arredondada (até $19 \mathrm{~mm}$ de comprimento), bem inflada, moderadamente forte, de cor branca (podendo ser acinzentada devido à influência do ambiente em que vive). Superfície externa lisa próximo aos umbos e superfície restante com linhas concêntricas finas e poucas linhas de crescimento espessadas. Dente cardinal anterior esquerdo e posterior direito sulcados ou bífidos. Cicatriz dos adutores grandes e subiguais.

Distribuição. Estados Unidos (Carolina do Norte a Flórida), Bermuda, Índias Ocidentais, Brasil à Região Magelânica e Ilha Chiloé, Chile. Moderadamente comum desde águas rasas a profundas, de um a aproximadamente $200 \mathrm{~m}$ de profundidade.

Phlyctiderma semiaspera (Philippi, 1836). Concha quase orbicular (raramente com mais de $12,5 \mathrm{~mm}$ de comprimento), inflada, semelhante a $D$. punctata quanto a cor e dentição, mas dotada de pústulas microscópicas arranjadas concentricamente nos interespaços das numerosas linhas de crescimento.

Distribuição. Estados Unidos (Carolina do Norte a Flórida e Texas), Índias Ocidentais, Brasil a Argentina (Golfo São Matias). Em fundos arenosos, águas rasas a profundas.

\section{Cardiidae}

Trachycardium muricatum (Linnaeus, 1758). Concha suboval (até $64 \mathrm{~mm}$ de comprimento), espessa, com 30 a 40 costelas radiais estreitas, fortes e com escamas, estas podendo estar ausentes na área do disco. Margem ventral crenulada. Coloração creme clara com manchas irregulares marrom-avermelhadas ou amareladas. Perióstraco castanho-acinzentado, opaco. Umbos grandes; lúnula alongada; ligamento externo, curto e proeminente. Charneira curta, reta ou abruptamente curvada, com dentição forte. Interior porcelanáceo, geralmente branco, não raro apresentando-se tinto, ou com manchas amareladas e/ou purpúreas ou róseas na concavidade umbonal.

Distribuição. Estados Unidos (Carolina do Norte e Texas), Índias Ocidentais, Venezuela, Brasil a Argentina (Golfo São Matias). Em areia lodosa ou em areia retida entre rochas.

Laevicardium laevigatum (Linnaeus, 1758). Concha mais alta que comprida (até $50 \mathrm{~mm}$ de comprimento), polida, lisa, ou com cerca de 60 costelas finas, obscuras. Coloração geralmente amarelada com linhas marrons em zigzag ou com manchas róseas ou purpúreas. Charneira arqueada, com dentes laterais proeminentes. Margem interna finamente serrilhada.

Distribuição. Estados Unidos (Carolina do Norte a Flórida e Texas), Bermuda, Índias Ocidentais, Venezuela, Suriname, Brasil (Amapá a Santa Catarina). Fundos arenosos, de águas rasas até $75 \mathrm{~m}$ de profundidade. 


\section{Mactridae}

Mactra fragilis Gmelin, 1791. Concha oval (até $100 \mathrm{~mm}$ de comprimento), comprimida, moderadamente fina mas forte, de cor branca-creme. Perióstraco fino, marrom-acinzentado, de brilho sedoso. Valvas não se tocam nas duas extremidades, deixando uma abertura posterior maior. Região dorsal posterior de cada valva com duas costelas baixas, irradiando a partir do umbo; a costela mais dorsal margeia o escudo. Superfície externa com finas linhas de crescimento, muito próximas entre si. Declive dorsal porterior entre as costelas radiais com perióstraco mais desenvolvido, escuro e enrugado. Ligamento dividido em duas partes, sendo a externa pequena.

Distribuição. Estados Unidos (Carolina do Norte a Flórida e Texas), Índias Ocidentais, Venezuela, Suriname, Brasil (Rio Grande do Norte a Santa Catarina). Em fundos arenosos, entremarés até $100 \mathrm{~m}$ de profundidade.

Mulinia cleryana (Orbigny, 1846). Concha trigonal (até $32 \mathrm{~mm}$ de comprimento), moderadamente obesa, lisa. Coloração creme clara sob perióstraco fino, laranja ou marrom-amarelado. Umbos centrais, proeminentes. Região dorsal posterior com elevação moderadamente distinta, irradiando-se a partir dos umbos. Ligamento totalmente interno. Valva esquerda com dentes laterais mais fortes que os da direita e equidistantes dos cardinais. Seio palial atingindo profundidade igual a $1 / 3$ do comprimento da linha palial.

Distribuição. Índias Ocidentais, Suriname, Brasil (Maranhão a Santa Catarina). Em fundos arenosos, águas rasas.

\section{Solenidae}

Solen tehuelchus Orbigny, 1843. Concha subretangular (até $61 \mathrm{~mm}$ de comprimento), inequilateral, frágil e translúcida. Razão comprimento/altura aproximadamente 6:1. Perióstraco fino, marrom-amarelado. Margem dorsal quase reta e paralela à ventral. Umbos terminais. Ligamento externo, longo, na altura do adutor anterior. Charneira com 1 dente cardinal em cada valva.

Distribuição. Brasil (Rio de Janeiro ao Rio Grande do Sul) a Argentina (Bahia Blanca). Fundos arenosos, águas rasas.

\section{Tellinidae}

Tellina (Eurytellina) lineata Turton, 1819. Concha moderadamente alongada (até $38 \mathrm{~mm}$ de comprimento), sólida, polida, com uma ligeira flexão posterior para a direita. Margem anterior arredondada, posterior angulosa e obliqüamente truncada. Cor branca, amarelada ou rosa. Ornamentação por numerosas linhas concêntricas, próximas e microscópicas. Charneira bem desenvolvida, com dentes laterais fortes na valva direita, ausentes na esquerda. Seio palial toca a cicatriz do adutor anterior.

Distribuição. Estados Unidos (Carolina do Norte a Flórida e Texas), Índias Ocidentais, Venezuela, Brasil (Ceará a Santa Catarina). Fundos arenosos, da região entremarés até $12 \mathrm{~m}$ de profundidade.

Tellina (Eurytellina) punicea Born, 1778. Concha alongada (até $45 \mathrm{~mm}$ de comprimento), fracamente inflada, com margem anterior arredondada e posterior 
angulosa, algo truncada. Coloração externa com faixas brancas e faixas vermelhas ou purpúreas. Ornamentação com sulcos concêntricos fracamente entalhados, separados por amplas faixas lisas. Charneira com dentes laterais na valva direita, ausentes na esquerda. Seio palial toca a cicatriz do adutor anterior.

Distribuição. Estados Unidos (Carolina do Norte a Flórida), Índias Ocidentais, Venezuela, Suriname, Brasil (Ceará a Santa Catarina). Fundos arenosos, águas rasas.

Tellina (Angulus) versicolor DeKay, 1843. Concha alongada (até 17,5 mm de comprimento), moderadamente inflada, fina, frágil, translúcida a transparente. Cor variando do branco ao vermelho, algumas com raios cor-de-rosa ou vermelhos na região posterior. Ornamentação por estrias concêntricas, finas. Seio palial ascendendo suavemente na porção posterior e se estendendo até muito próximo da cicatriz do músculo anterior.

Distribuição. Estados Unidos (Nova Iorque a Flórida), Bermuda, Índias Ocidentais, Leste do Panamá, Brasil (Ceará, São Paulo e Santa Catarina). Fundos arenosos, da região entremarés até $50 \mathrm{~m}$ de profundidade.

Strigilla (Strigilla) carnaria (Linnaeus, 1758). Concha subcircular (até 16 $\mathrm{mm}$ de comprimento), moderadamente inflada e valva direita mais convexa. Coloração geral rosa, ou com margem branca. Superfície externa com sulcos oblíquos uniformemente espaçados, formando um "V" na região posterior. Seio palial não toca a cicatriz do músculo adutor anterior. Charneira com 2 dentes cardinais em cada valva ( 1 bífido), 2 laterais fortes na valva direita e 2 laterais fracos na esquerda.

Distribuição. Estados Unidos (Carolina do Norte a Flórida), Índias Ocidentais, toda costa brasileira até Argentina (Bahia Blanca). Fundos arenosos, águas rasas.

Macoma cleryana (Orbigny, 1846). Concha oval (até $34 \mathrm{~mm}$ de comprimento), ornamentada com finas linhas de crescimento. Coloração branca, com umbos laranja-avermelhados. Interior branco com faixas avermelhadas e alaranjadas iniciando nos umbos.

Distribuição. Suriname, Brasil (Amapá a Santa Catarina). Em substratos arenosos e areno-lodosos, da região entremarés até $40 \mathrm{~m}$ de profundidade.

Macoma constricta (Bruguière, 1792). Concha suboval (até $57 \mathrm{~mm}$ de comprimento), algo sólida, e ornamentada com numerosas estrias finas, concêntricas. Coloração branca sob perióstraco acinzentado, semi-descíduo e corrugado no declive posterior. Extremidade posterior flexionada para a direita. Margens anterior e ventral arredondadas. Charneira fraca. Seio palial amplamente arqueado.

Distribuição. Estados Unidos (Carolina do Norte a Flórida e Texas), Índias Ocidentais, Suriname, Brasil (Pará a Santa Catarina). Fundos arenosos, águas rasas.

Macoma uruguayensis (E. A. Smith, 1885). Concha oval-oblonga (até 22 $\mathrm{mm}$ de comprimento), frágil, branca. Extremidade anterior arredondada, posterior truncada. Superfície com fracas linhas de crescimento. Umbos levemente opistogiros.

Distribuição. Brasil (São Paulo e Rio Grande do Sul) a Argentina (Bahia Blanca). Fundos areno-lodosos, da região entremarés até $70 \mathrm{~m}$ de profundidade. 


\section{Semelidae}

Semele proficua (Pulteney, 1799). Concha suborbicular (até $38 \mathrm{~mm}$ de comprimento), aproximadamente eqüivalve, moderadamente inflada. Lúnula pequena, oval-alongada, mais desenvolvida na valva direita. Escudo pouco conspícuo e porção externa do ligamento situada posteriormente aos umbos. Ornamentação das valvas constituída por finas estriações concêntricas e estrias radiais microscópicas. Coloração esbranquiçada ou amarelada. Interior branco ou amarelo-ouro, brilhante, com ou sem manchas purpúreas ou marrom-avermelhadas.

Distribuição. Estados Unidos (Carolina do Norte a Flórida e Texas), Bermuda, Índias Ocidentais, Brasil a Argentina (Golfo São Matias). Em fundos arenosos e areno-lodosos, mesmo quando retidos entre rochas. Da região entremarés até 75 $m$ de profundidade.

Semele purpurascens (Gmelin, 1791). Concha ovalada (até 38,5 mm de comprimento), ineqüivalve. Lúnula, escudo e ligamento semelhantes aos de $S$. proficua. Ornamentação das valvas constituída por finas estrias, concêntricas na valva direita e acêntricas na esquerda, neste caso ligeiramente inclinadas no sentido ântero-posterior e defasadas em relação às linhas de crescimento. Estrias radiais fracas, pouco numerosas e de difícil observação mesmo ao microscópio. Coloração creme, rósea ou vermelha-alaranjada, salpicada com manchas púrpura-acastanhadas, sem arranjo definido ou formando zigzags. Exemplares albinos foram registrados para o litoral paulista. Interior da concha brilhante, esbranquiçado na periferia, com manchas de cor púrpura escura, ou castanha, às vezes entremeadas de branco nos limites internos à linha palial. Interior róseo, vermelho-alaranjado, púrpuraacastanhado ou mesmo branco puro (nos albinos) é encontrado entre os espécimes do litoral paulista.

Distribuição. Leste do Pacífico (Golfo da Califórnia ao Equador e Ilhas Galápagos), Estados Unidos (Carolina do Norte e Texas), Índias Ocidentais, Suriname, Brasil ao Uruguai. Fundos arenosos e areno-lodosos, águas rasas do infralitoral até $650 \mathrm{~m}$ de profundidade.

Abra lioica (Dall, 1881). Concha oval-trigonal (até $8 \mathrm{~mm}$ de comprimento), frágil, lisa, branca, translúcida. Umbos pequenos, subcentrais, situados na metade anterior. Margem anterior da valva direita sem sulcos ou estrias. Valva direita com dois cardinais e laterais obsoletos; valva esquerda com apenas um cardinal. Seio palial amplo e confluente com a linha palial.

Distribuição. Estados Unidos (Carolina do Norte a Flórida), Índias Ocidentais, Brasil (Ceará, São Paulo e Santa Catarina) a Argentina (Mar del Plata). Fundos arenosos, da região entremarés até $360 \mathrm{~m}$ de profundidade.

Ervilia nitens (Montagu, 1808). Concha oval, algo alongada mas não rostrada (até $12 \mathrm{~mm}$ de comprimento), inequilateral. Superfície externa com estrias radiais confinadas à região posterior dorsal das valvas, e estrias concêntricas numerosas e igualmente desenvolvidas. Coloração branca, ocasionalmente com manchas róseas ou amareladas na região umbonal. Umbos subcentrais anteriores. Charneira com um dente cardinal grande na valva direita, imediatamente anterior ao condróforo; valva esquerda com dois dentes cardinais anteriores ao condróforo, 
divergentes e com uma profunda depressão entre eles, onde se encaixa o cardinal da valva oposta. Laterais ausentes, mas a valva esquerda tem um sulco alongado em sua margem dorsal onde se encaixa a margem correspondente da valva oposta. Ligamento externo opistodético e pouco conspícuo, e ligamento interno (resílio) preso a um condróforo na linha do umbo.

Distribuição. Estados Unidos (Flórida), Bermuda, Bahamas, Índias Ocidentais, Brasil (Maranhão a São Paulo). Fundos arenosos, da região entremarés até 50 $m$ de profundidade.

Nota sistemática. O gênero Ervilia, pelas características da concha, foi classificado inicialmente como Erviliinae, Mesodesmatidae (Dall, 1895), e mais recentemente realocado por MORTON \& SCOTT (1990) para Tellinacea, devido à presença de músculo cruciforme diagnóstico para esta superfamília, e na família Semelidae, pelas características do ligamento com ambos os elementos externo e interno, e pela dentição da charneira fracamente desenvolvida.

\section{Solecurtidae}

Tagelus plebeius (Lightfoot, 1786). Concha oblonga (até $87 \mathrm{~mm}$ de comprimento), lisa, com extremidade posterior arredondada, e anterior obliqüamente truncada. Coloração branca com manchas violetas. Perióstraco espesso, verde-oliva a marrom-amarelado. Superfície com ranhuras concêntricas. Umbos indistintos, próximos entre si, subcentrais posteriores. Charneira com uma grande calosidade bulbosa posterior aos dentes cardinais.

Distribuição. Estados Unidos (Carolina do Norte a Flórida e Texas), Índias Ocidentais, Venezuela, Suriname, Brasil até o sudeste da Argentina. Geralmente em estuários e baías em fundos arenosos e areno-lodosos, da região entremarés até $10 \mathrm{~m}$ de profundidade.

Tagelus divisus (Spengler, 1794). Concha com a extremidade anterior arredondada e posterior mais baixa e angulosa (até $38 \mathrm{~mm}$ de comprimento), frágil e lisa. Coloração roxa-acinzentada ou esbranquiçada, com raios de cor púrpura. Perióstraco muito fino, polido, castanho escuro a marrom. Valvas reforçadas internamente por uma costela mediana, fraca a obsoleta, radiando a partir dos dentes cardinais.

Distribuição. Estados Unidos (Carolina do Norte a Flórida e Texas), Índias Ocidentais, Venezuela, Brasil (Alagoas a Santa Catarina). Substratos arenosos, águas rasas.

\section{Veneridae}

Chione subrostrata (Lamarck, 1818). Concha subtrigonal-arredondada a ovalada (até $35 \mathrm{~mm}$ de comprimento), moderadamente inflada, forte. Ornamentação constituída por numerosas lamelas concêntricas, ligeiramente elevadas e onduladas, e por costelas radiais constituídas por uma ou duas barras inseridas nos interespaços das lamelas, gerando um padrão subcancelado. Declive anterior com costelas radiais mais alargadas e bem marcadas, ou obsoletas. Umbos baixos, arredondados e prosógiros. Lúnula cordiforme, bem definida por um sulco fino, profundo e ornamentada com costelas radiais conspícuas, cruzadas por lâminas concêntricas. Cor da lúnula parcial ou completamente marrom, às vezes contrastando com a cor da 
concha. Escudo longo, lanceolado, marrom-acastanhado. Coloração da concha geralmente branca-amarelada ou acinzentada, com ou sem faixas radiais ou desenhos irregulares e escuros. Dentição cardinal com o dente mediano mais desenvolvido, notadamente na valva esquerda. Laterais ausentes. Interior branco, com ou sem manchas violáceas, e margens das valvas crenuladas. Seio palial oblíquo, triangular com ápice arredondado.

Distribuição. Estados Unidos (Sul da Flórida), Índias Ocidentais, Venezuela, Suriname, Brasil (Amapá ao Ceará, Alagoas, Rio de Janeiro e São Paulo). Em areia lodosa, junto a fragmentos de rochas e conchas em baías e enseadas.

Chione cancellata (Linnaeus, 1767). Concha (até $25 \mathrm{~mm}$ de comprimento) semelhante à espécie precedente, dela diferindo pela ornamentação por lamelas concêntricas mais fortes, elevadas e espaçadas e, nos interespaços destas, por costelas radiais mais largas, arredondadas, fracamente divididas em barras. Lúnula cordiforme, com ornamentação concêntrica mais conspícua que a radial nos indivíduos gerônticos. Escudo longo, lanceolado, largo, liso, geralmente só com a cor da concha, ou com seis ou sete listras transversais marrons. Coloração da concha geralmente branca ou acinzentada. Dentição similar à de $C$. subrostrata. Interior branco com manchas violáceas e margens crenuladas. Seio palial oblíquo, raso, de ápice subanguloso.

Distribuição. Estados Unidos (Carolina do Norte a Flórida e Texas), Índias Ocidentais, Venezuela, Suriname ao Brasil (Amapá a Santa Catarina). Em fundos arenosos, areno-lodosos, mesmo quando recobertos por rochas.

Chione intapurpurea (Conrad, 1849). Concha oval a trigonal (até $48 \mathrm{~mm}$ de comprimento), espessa, ornamentada com numerosas lamelas concêntricas elevadas, mais desenvolvidas nos declives anterior e posterior, e com costelas radiais baixas, arredondadas, inseridas nos interespaços das lamelas. Estas lamelas apresentam na face ventral numerosas barras que se alinham radialmente com as barras das lamelas adjacentes. Lúnula cordiforme, marrom, e escudo lanceolado, este mais desenvolvido na valva esquerda. Lúnula e escudo ornamentados por numerosas lamelas finas. $\mathrm{Na}$ lúnula, estas lamelas equivalem ao prolongamento das lamelas encontradas sobre as valvas. Coloração externa branca brilhante a creme, com manchas marrons irregulares. Interior branco ou com faixas ou manchas violáceas. Seio palial oblíquo, raso, com ápice subanguloso.

Distribuição. Estados Unidos (Carolina do Norte a Flórida e Texas), Índias Ocidentais, Venezuela, Brasil (Amapá a São Paulo). Fundos arenosos, da região entremarés até $85 \mathrm{~m}$ de profundidade.

Anomalocardia brasiliana (Gmelin, 1791). Concha subtrigonal (até 38,2 $\mathrm{mm}$ de comprimento), forte, moderadamente inflada. Ornamentação constituída por costelas concêntricas fortes, baixas, com estrias radiais pouco conspícuas inseridas nos interespaços. Coloração creme, ou creme com manchas marrons ou purpúreas com diversos padrões de distribuição e arranjo. Lúnula e escudo grandes, pouco escavados, freqüentemente com listras violáceas dispostas transversal ou obliqüamente. Interior branco, liso, geralmente com uma faixa radial marrom-violácea na região posterior. Nestes casos, a charneira pode ser tingida desta mesma cor. Margem ventral interna crenulada. Seio palial muito raso. 
Distribuição. Índias Ocidentais, Suriname, Brasil ao Uruguai. Fundos areno-lodosos, águas rasas, calmas.

Transennella stimpsoni Dall, 1902. Concha trigonal-arredondada, pequena (até $15 \mathrm{~mm}$ de comprimento), lisa, a não ser pelas finas linhas de crescimento e polida. Coloração creme, com faixas radiais marrom claras. Interior branco-creme com manchas violáceas. Extremidade posterior menos alongada que a anterior. Margem interna com sulcos oblíquos microscópicos, que se tornam paralelos às linhas de crecimento na margem ventral das valvas. Seio palial longo, estendendo-se até a linha mediana de cada valva. Escudo ausente.

Distribuição. Estados Unidos (Carolina do Norte a Flórida), Bahamas, Brasil (Ceará a Santa Catarina e Abrolhos). Em areia recoberta por pedras, desde águas rasas na região entremarés até $6 \mathrm{~m}$ de profundidade.

Gouldia cerina (C.B. Adams, 1845). Concha trigonal (até $11 \mathrm{~mm}$ de comprimento), sólida, levemente inflada, com umbos centrais altos e muito pequenos. Ornamentação constituída por costelas finas, concêntricas e costelas radiais, estas mais fortes e conspícuas nas regiões anterior e posterior da concha. Coloração branca-amarelada, podendo apresentar manchas marrons ou violáceas. Lúnula alongada e bem demarcada. Escudo ausente. Dente cardinal mediano da valva esquerda ligeiramente bífido; lateral anterior presente na valva esquerda e respectivo encaixe na direita. Seio palial muito raso.

Distribuição. Estados Unidos (Carolina do Norte a Flórida), Bermuda, Índias Ocidentais, Suriname, toda costa brasileira. Em areia, mesmo a recoberta por pedras, desde águas rasas até $170 \mathrm{~m}$ de profundidade.

Pitar fulminatus (Menke, 1828). Concha suboval (até $45 \mathrm{~mm}$ de comprimento), inflada, lisa, com linhas de crescimento fortes, formando uma ornamentação concêntrica. Coloração creme, com manchas ou linhas em zigzag marrons, geralmente arranjadas radialmente. Extremidade anterior ampla, arredondada; posterior reduzida e subangular. Umbos anteriores, proeminentes; lúnula cordiforme obsoleta, grande, delimitada por um fino sulco. Escudo longo e obsoleto. Dente lateral proeminente na valva esquerda e respectivo encaixe na direita.

Distribuição. Estados Unidos (Carolina do Norte a Flórida), Índias Ocidentais, Venezuela, Suriname, Brasil (Amapá a Santa Catarina). Fundos arenosos e lodosos, águas rasas.

Pitar palmeri Fischer-Piette \& Testud, 1967. Concha (até $37 \mathrm{~mm}$ de comprimento) com características muito semelhantes às de $P$. fulminatus, da qual difere particularmente pela coloração geral que é marrom clara a marrom levemente violácea, com faixas brancas e/ou marrons escuras, estreitas e contínuas.

Distribuição. Brasil (Rio de Janeiro a Santa Catarina). Fundos arenosos, da região entremarés até $45 \mathrm{~m}$ de profundidade.

\section{Corbulidae}

Corbula caribaea Orbigny, 1842. Concha subtriangular-ovalada (até $9 \mathrm{~mm}$ de comprimento), inflada. Metade anterior da concha com declive ligeiramente convexo e margens anterior e ventral arredondadas. Metade posterior da concha com margem dorsal de declive suave, ligeiramente côncavo na valva esquerda e 
quase reto na direita, confluíndo, em ambas as valvas, em ângulo agudo com a margem ventral, o que concorre para o formato em bico da extremidade posterior. Esta é truncada em posição subdistal. Ornamentação constituída por numerosas costelas concêntricas irregulares. Valva direita nitidamente mais desenvolvida e se sobrepondo nas margens ventral e posterior à valva esquerda. Ambas as valvas com um cardinal robusto. Cor branca. Umbos pequenos e achatados.

Distribuição. Estados Unidos (Carolina do Norte a Flórida e Texas), Índias Ocidentais, Suriname, Brasil (todo o litoral e Ilha Santa Helena), Uruguai, Argentina (Golfo Nuevo). Em fundos areno-lodosos.

Corbula cubaniana Orbigny, 1853. Concha romboidal (até $7 \mathrm{~mm}$ de comprimento), subeqüivalve, levemente inequilateral. Metade anterior da concha com margem dorsal convexa, e margens anterior e ventral arredondadas. Metade posterior da concha com margem dorsal curta, e margem posterior obliqüamente truncada, alta, terminando em ângulo agudo na sua confluência com a margem ventral. Superfície com numerosas costelas concêntricas regulares. Coloração branca. Umbos pequenos e achatados. Ambas as valvas com um dente cardinal robusto.

Distribuição. Estados Unidos (Flórida), Índias Ocidentais, Suriname, Brasil (Ceará a São Paulo). Em substratos areno-lodosos, da região entremarés até $40 \mathrm{~m}$ de profundidade.

Thraciidae

Thracia similis Couthouy, 1839. Concha oval-alongada (até $37 \mathrm{~mm}$ de comprimento), frágil. Extremidade anterior arredondada, posterior truncada. Ornamentação constituída por linhas de crescimento espessadas, concêntricas, irregulares e grânulos microscópicos por toda superfície, mas em geral melhor preservados próximo às margens ventral e posterior. Valvas com uma quilha oblíqua estendendo-se do umbo à região póstero-ventral. Ligamento externo e interno presentes, este último, preso a um condróforo oblíquo, posterior ao umbo. Seio palial largo.

Distribuição. Brasil (Rio de Janeiro) ao Uruguai. Em substratos arenosos e areno-lodosos, da região entremarés até $35 \mathrm{~m}$ de profundidade.

AGRADECIMENTOS. Ao Centro de Biologia Marinha da USP (CEBIMar), pelas facilidades concedidas; aos técnicos Elso, Adriano, Joseilton e Moisés do CEBIMar, Élsio Soares Marinho (IB-UNICAMP) e ao Luis Henrique de Lima, à Erica Veronica Pardo e à Margarete de Oliveira Reis, pela ajuda nos trabalhos de campo. À CAPES e ao FAEP/UNICAMP, pelo apoio financeiro.

\section{REFERÊNCIAS BIBLIOGRÁFICAS}

Aввотт, R.T. 1974. American Seasheels. Van Nortrand Reinhold Company, 663p. ABBotT, R.T. \& S.P. DANCE. 1991. Compendium of Seashells. London, Charles Letts e Co. Ltd., $411 \mathrm{p}$.

AMARAL, A.C.Z.; E.H. MoRgado; P.P. LOPES; L.F. BELÚCIO; F.P.P. LEITE \& C.P. FERREIRA. 1990. Composition and distribution of the intertidal macrofauna of sandy beaches on São Paulo coast. In: Anais II Simpósio de Ecossistemas da 
Costa Sul e Sudeste Brasileira. Estrutura, Função e Manejo. Publ. Aciesp, São Paulo, 3: 258-273.

Boss, K.J. 1966. The subfamily Tellinidae in the Western Atlantic. The genus Tellina (Part I). Johnsonia 4 (45): 217-344.

Coelho, A.C.S. \& D.R.B. CAMPos. 1975. Contribuições ao conhecimento dos moluscos do Rio de Janeiro, Brasil. 1 Bivalvia, Pteriomorphia, Arcoida, Arcoidea. Arq. Mus. Nacio. 55: 35-57.

DANCE, P. 1990. The Collectors Encyclopedia of Shells. Chartwell Books Inc., $288 \mathrm{p}$.

DAVIS, J.D. 1973. Systematics and distribution of Western Atlantic Ervilia (Pelecypoda: Mesodesmatidae) with notes on the living Ervilia subcancellata. The Veliger 15 (4): 307-313.

DOMANESCHI, O. 1995. A comparative study of the functional morphology of Semele purpurascens (Gmelin, 1791) and Semele proficua (Pulteney, 1799) (Bivalvia: Semelidae). The Veliger 38 (4): 323-342.

EISENBERG, J.M. 1983. Conchiglie - 4000 esemplari da tutto il mondo. Novana, Itália, Instituto Geográficode Agostini, 223p.

KAAS, P. \& R.A. VAN BELLE. 1985. Monograph of Living Chitons. (Mollusca:

Polyplacophora). London, E.J. Brill/Dr. W. Backhuys, vol. 2, 198p.

- 1987. Monograph of living chitons (Mollusca: Polyplacophora). London, E.J. Brill/Dr. W. Backhuys, vol.3, 302p.

KeEN, A.M. 1971. Sea Shells of Tropical West America. Stanford, Stanford University Press, 1064p.

LEAL, J.H. 1991. Marine Prosobranch Gastropods from Oceanic Islands off Brazil. Oegstgeest, Universal Book, Services, Dr. W. Backhuys: III, 418p.

LOPES, S.G.B.C. 1992. Bivalves e gastrópodes do Saco da Ribeira, Ubatuba - São Paulo. I. Levantamento, distribuição das espécies e características ambientais.

Bolm. Zool. Univ. São Paulo 13: 9-49.

MigotTo, A.E.; C.G. TIAGO \& A.R.M. MAgAlHãES. 1993. Malacofauna marinha da região costeira do Canal de São Sebastião, SP, Brasil: Gastropoda, Bivalvia, Polyplacophora e Scaphopoda. Bolm. Inst. oceanogr., S. Paulo, 41 (1-2): 13-27. Morgado, E.H.; A.C.Z. AMARAL; L.F. BelúCiO; P.P. Lopes \& C.P. FERREIRA. 1990. Compositon and distribution of the intertidal macrofauna of São Francisco Complex Beaches. In: Anais II Simpósio de Ecossistemas da Costa Sul e Sudeste Brasileira. Estrutura, Função e Manejo. Publ. Aciesp, São Paulo, 3: 314-325.

MORTON, B. 1990. The bilogy and functional morphology of Ervilia castanea (Bivalvia: Tellinacea) from the Azores, p.75-96. In: A.M. FrIAS MARTINS (Ed.). Proceedings of the first international workshop on the malacofauna of the Azores, 1988. Açoreana, supplement.

MORTON, B. \& P.H. SCOTT. 1990. Relocation of Ervilia Turton, 1822 (Bivalvia) from the Mesodesmatidae (Mesodesmatoidea) to the Semelidae (Tellinoidea). The Veliger 33 (3): 299-304.

NARCHI, W. 1972. Comparative study of the functional morphology of Anomalocardia brasiliana (Gmelin, 1791) and Tivela mactroides (Born, 1778) (Bivalvia, Veneridae). Bull. Mar. Sci. 22 (3): 643-670.

NARCHI, W. \& M.A. GABRIELI. 1980. Sobre anatomia funcional de Chione subros- 
trata (Lamarck, 1818). Rev. Nordest. Biol., Recife, 3 (especial): 25-46. Oliveira, M.P. \& M.H.R. OliveIRA. 1974. Dicionário Conquílio Malacológico. Juiz de Fora, Universidade Federal de Juiz de Fora, 189p.

RighI, G. 1971. Moluscos poliplacóforos do Brasil. Papéis Avulsos Zool., São Paulo, 24 (9): 123-146.

Rios, E.B. 1985. Seashells of Brasil. Rio Grande, Fundação Universidade do Rio Grande, 328p. 1994. Seashells of Brasil. Rio Grande, Fundação Universidade do Rio Grande, 368p.

Suguio, K. 1973. Introdução à Sedimentologia. São Paulo, Edgard Blucher, Edusp, 312p.

WARMKe, G.L. \& R.T. AввотT. 1975. Caribbean Seashells. New York, Dover publications, $348 \mathrm{p}$.

Recebido em 26.IX.1997; aceito em 10.XI.1998. 